\title{
Genomic organisation of the UDP-N-acetylglucosamine-1- phosphotransferase gamma subunit (GNPTAG) and its mutations in mucolipidosis III
}

\author{
A Raas-Rothschild, R Bargal, O Goldman, E Ben-Asher, J E M Groener, A Toutain, E Stemmer, \\ Z Ben-Neriah, H Flusser, F Á Beemer, M Penttinen, T Ólender, A J J T Rein, G Bach, M Zeigler
}

$F^{i}$ irst described by Maroteaux and Lamy in 1966, mucolipidosis III (ML III) or pseudo-Hurler polydystrophy (MIM 252600; Online Mendelian Inheritance in Man (OMIM), McKusick-Nathans Institute for Genetic Medicine, Johns Hopkins University (Baltimore, MD) and National Center for Biotechnology Information, National Library of Medicine (Bethesda, MD), 2000; http:// www.ncbi.nlm.nih.gov/omim/) is a rare autosomal recessive condition resembling Hurler syndrome with no organomegaly or mucopolysacchariduria.

Clinical manifestations are variable and progress into adulthood. Bone involvement is slowly progressive and bone pain and disability due to destruction of hip joints are the most frequent and debilitating symptoms. Clinical symptoms include stiffness of the fingers and shoulders, claw hand deformity, short stature, and scoliosis. Mild coarsening of the face with corneal clouding, mild retinopathy, astigmatism, and cardiac valve involvement have also been reported. The radiological findings include moderate to severe dysostosis multiplex with vertebral changes.

ML III is due to the abnormal trafficking and subcellular localisation of lysosomal enzymes. ${ }^{3-5}$ Newly synthesised lysosomal enzymes are secreted into the extracellular medium instead of being properly targeted to the lysosomes because they lack a mannose 6-phosphate receptor recognition marker. ${ }^{3}$ The UDP- $N$-acetylglucosamine-1-phosphotransferase enzyme activity is defective in $\mathrm{ML} \mathrm{III}^{6}$ and three complementation groups (A, B, C) have been reported suggesting genetic heterogeneity. ${ }^{7}$ ML III complementation group C (MIM 252605) is characterised by deficient enzyme activity when assayed with lysosomal glycoproteins as acceptors, but normal activity when assayed with the simple acceptor, $\alpha$-methylmannoside. ${ }^{6} 8$ In 1996, Bao et al ${ }^{9}$ showed that UDP- $N$-acetylglucosamine-1-phosphotransferase is a multimeric enzyme made up of three different subunits. We have previously ascribed ML III type C to mutations in the UDP- $N$-acetylglucosamine-1-phosphotransferase gamma subunit gene (GNPTAG) on chromosome $16 \mathrm{p} .{ }^{10}$ Here, we report the genomic structure of this gene and its mutations in 14 additional patients belonging to eight families of various ethnic backgrounds. We suggest that, although the exact relative frequency of each ML III type is not known, the UDP$\mathrm{N}$-acetylglucosamine-1-phosphotransferase gamma subunit gene apparently plays a major role in mucolipidosis type III.

\section{METHODS}

Patients

The 14 patients reported here belong to eight families of Jewish Tunisian (3/8), Druze (1/8), Turkish (1/8), Dutch $(1 / 8)$, Finnish (1/8), and Jewish-Iranian origin (1/8). Five families were consanguineous. The diagnosis of ML III was based on a combination of clinical, radiological, and

\section{Key points}

- Our work aimed to identify new mutations in the UDP$\mathrm{N}$-acetylglucosamine-1-phosphotransferase gamma subunit gene (GNPTAG) and to collect clinical data on 14 patients affected with mucolipidosis type III.

- We studied the 11 exons of the GNPTAG gene by direct sequence analysis in a group of 14 patients belonging to eight families of different background origin.

- We observed six new mutations in the GNPTAG gene. Mutant genotypes included missense, frameshift, and splice mutations in Druze (1/8: G106S), JewishTunisian (3/8: c.500insC), Jewish-Iranian (1/8: c. 445 delG), Turkish (1/8: c.608insC), Finnish (1/8: c.379del13bp), and Dutch patients (1/8: IVS5-1G >C and R66X).

- We emphasise the aortic and mitral valve involvement in mucolipidosis III patients. A careful cardiac evaluation in order to detect severe valvular complications is recommended.

- This study strongly suggests that the gamma subunit of the UDP-N-acetylglucosamine-1-phosphotransferase gene might play a major role in mucolipidosis type III.

biochemical criteria. $^{2}$ The clinical criteria included: short stature, progressive joint contractures, mild mental retardation, fine corneal opacities, valvular heart disease, thoracic and spine deformities, and coarse facies. ${ }^{2}$

Radiological inclusion criteria were dysostosis multiplex with unique pelvic and vertebral changes. ${ }^{2}$ Biochemical criteria consisted in an at least 10-fold increase in serum lysosomal enzyme activity level (arylsulfatase A, betahexosaminidase, alpha mannosidase) and/or low intracellular lysosomal enzyme activity level in cultured fibroblasts (14/14 patients).

Most patients presented with hand stiffness and claw hand deformity (11/14), stiffness of shoulders (7/14), scoliosis and/ or kyphosis $(8 / 14)$, and short stature $(7 / 14)$, with pectus carinatum and/or thoracic asymmetry (6/14) (table 1). Hip pain was a major complaint in four patients (aged 17, 28, 33, and 35 years). Patient 5-II presented with hip osteochondritis while his asymptomatic brother (5-III) and sister (5-IV) were

Abbreviations: GNPTAG, UDP-N-acetylglucosamine-1phosphotransferase gamma subunit gene; ML, mucolipidosis 


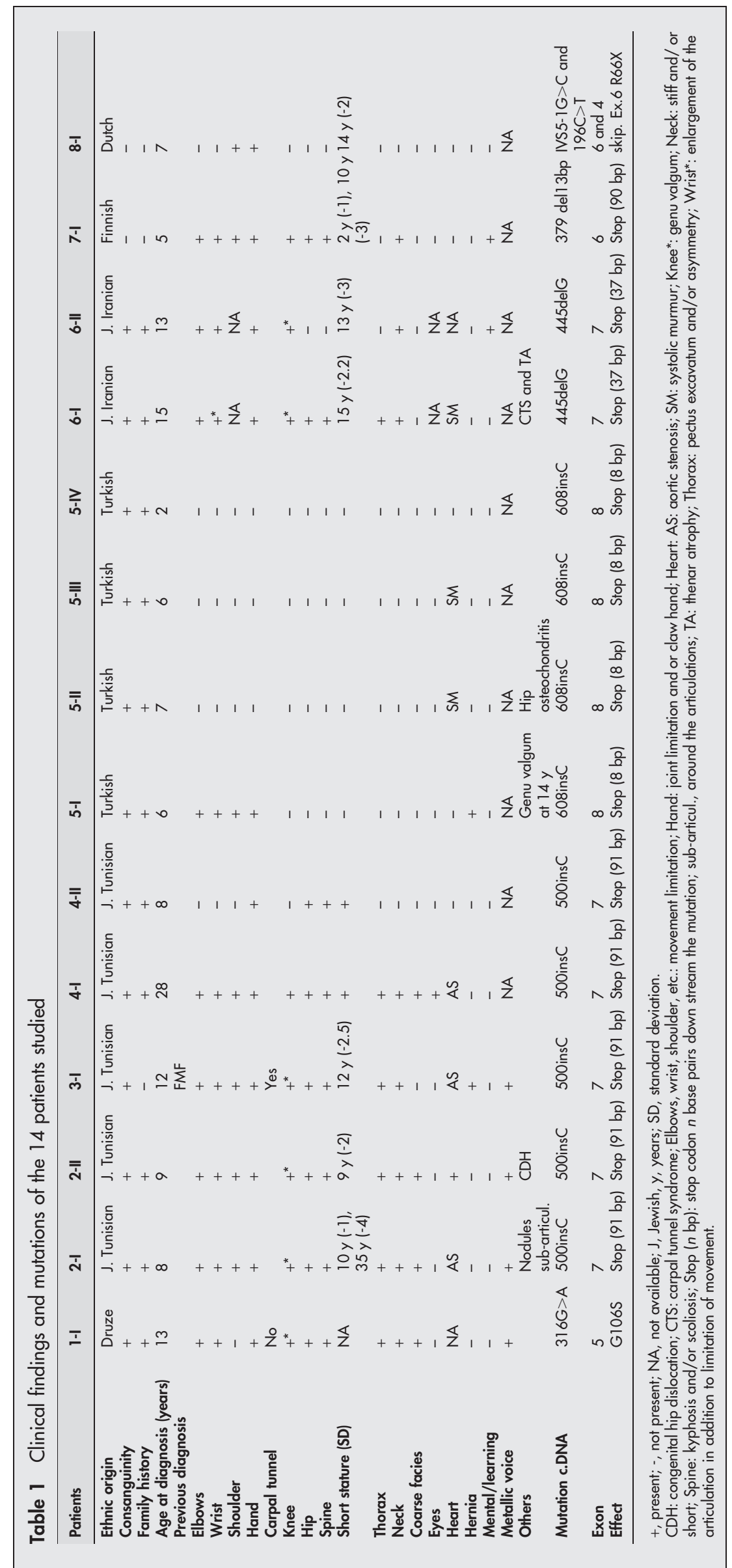




\begin{tabular}{|c|c|c|c|}
\hline Exon & Intron: 3'splice acceptor & Intron: 5'splice donor & Size (kb) \\
\hline $\begin{array}{l}1(20037-0088) \\
2(20173-0230) \\
3(20310-0377) \\
4(29814-9868) \\
5(29943-0026) \\
6(30109-0202) \\
7(30277-0391) \\
8(30523-0605) \\
9(30682-0813) \\
10(30896-0977) \\
11(31068-1162)\end{array}$ & $\begin{array}{l}\text { gctccccgtagGGCCCGCGCC... } \\
\text { cttcccgtagGGTGAACAAC... } \\
\text { tctcttccagGACCCGTGCA.. } \\
\text { gtgtccccagGTACAAGTAT... } \\
\text { gtctccccagCATCTGGCAC... } \\
\text { tccct ccccagGTGGAGCTGG... } \\
\text { gggtcctcagTGTACCCAAC... } \\
\text { tccaccttcagGGCCATGAGA... } \\
\text { gtggttggtagGCTCATAAAG... } \\
\text { tgttltgggcagAAACTCCAA... }\end{array}$ & 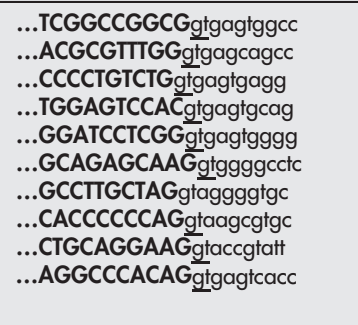 & $\begin{array}{r}52 \\
58 \\
68 \\
55 \\
83 \\
94 \\
115 \\
115 \\
83 \\
132 \\
82 \\
95\end{array}$ \\
\hline & Primers for PCR & & \\
\hline 1,2 & $\begin{array}{l}\text { 5'-Forward -3' } \\
\text { 5'-Reverse-3' }\end{array}$ & $\begin{array}{l}\text { GTCACGTGACCGTCACTTCAC } \\
\text { AGGCTGCTCACCCAAACGCGT }\end{array}$ & 253 \\
\hline 3 & $\begin{array}{l}\text { 5'-Forward -3' } \\
5^{\prime} \text {-Reverse-3' }\end{array}$ & $\begin{array}{l}\text { AGGTGCAGCGAAGATGAAGGT } \\
\text { GTCACTCATCCATCCTCCAC }\end{array}$ & 267 \\
\hline 4 & $\begin{array}{l}\text { 5'-Forward -3' } \\
5^{\prime} \text {-Reverse-3' }\end{array}$ & $\begin{array}{l}\text { CAGACAGGTTCTGTGCTTGG } \\
\text { GGACACAGATGGCATGAGG }\end{array}$ & 175 \\
\hline $4,5,6,7$ & $\begin{array}{l}\text { 5'-Forward -3' } \\
5^{\prime} \text {-Reverse-3' }\end{array}$ & $\begin{array}{l}\text { CAGACAGGTTCTGTGCTTGG } \\
\text { CACTGGGCTCAACTGCGTC }\end{array}$ & 659 \\
\hline 8,9 & $\begin{array}{l}\text { 5'-Forward -3' } \\
5^{\prime} \text {-Reverse-3' }\end{array}$ & $\begin{array}{l}\text { CTGAGCCTGGCTTCTCTTGG } \\
\text { GAGICAAGGGAAAGCCCAG }\end{array}$ & 384 \\
\hline 10,11 & $\begin{array}{l}5^{\prime} \text {-Forward -3' } \\
5^{\prime} \text {-Reverse-3' }\end{array}$ & $\begin{array}{l}\text { CTGGGCTTTCCCTTGAACTC } \\
\text { GTCCTACCAGCCAGCTTCTC }\end{array}$ & 367 \\
\hline
\end{tabular}
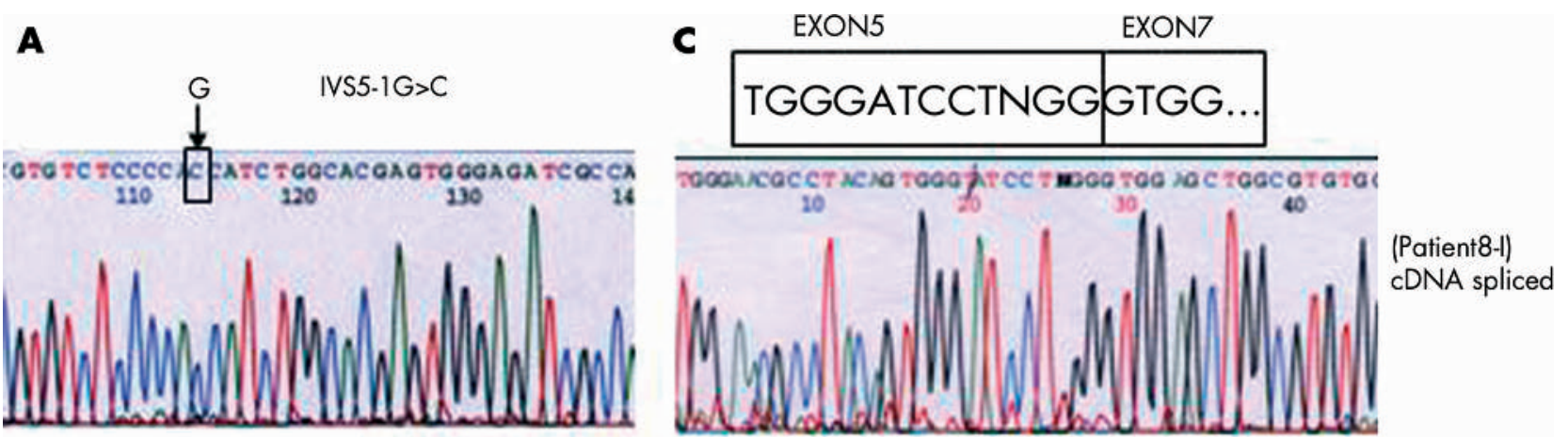

B

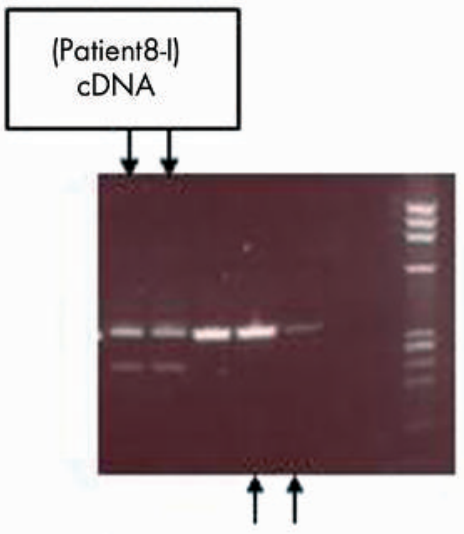

Control cDNA
D
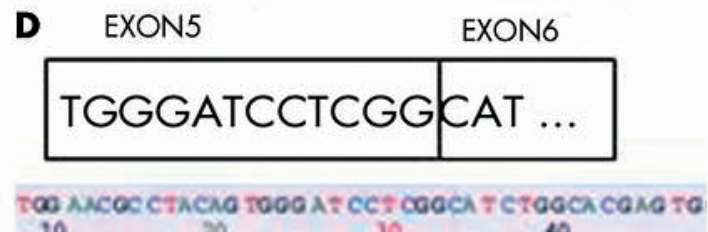

$10 \quad 30 \quad 30$

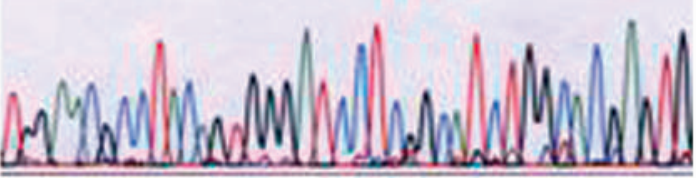

Control cDNA

Figure 1 Effect of IVS5-1G>C in patient 8-I. (A) Mutation IVS5-1G>C at the genomic level. (B) RNA was extracted from fibroblasts (RNA extraction kit, Qiagen). Reverse transcription (AMV reverse transcriptase, Boehringer) was carried out according to the manufacturer's instructions using the following primers (RT-PCR): forward (c. 254): GTTCCACAACGTGACCCAGCA and reverse (c.580): TGATCAGCTCATCGGCCAGGT. (C) Skipping of exon 6 at the c.DNA level in patient 8-I, compared to a normal control (D). 


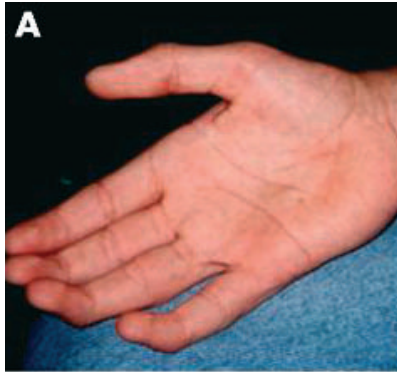

Figure 2 (A) Claw hands of patient (3-I) at the age of 12 years and (B) hand of patient 2-II at the age of 35 years.

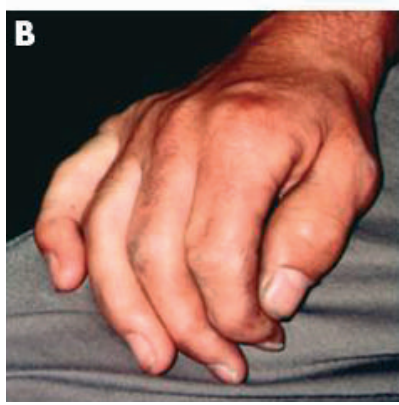

diagnosed on the basis of systematic biochemical tests performed because of the family history.

All the patients presented with variable degrees of dysostosis multiplex and progressive hip destruction. Low iliac wings with hypoplastic bodies, flattening and irregularity of the proximal femoral epiphyses, and underdevelopment of the anterior part of the vertebral bodies of the lumbar spine were also observed (11/14). Cardiac ultrasound showed a thickened aortic valve with aortic regurgitation in three of these patients. One patient (2-I) needed valve replacement therapy at the age of 27 years. A 17 year old patient (3-I) with severe aortic regurgitation is scheduled for surgery. Four patients had coarse facies, one had mild mental retardation (6-II), and one (7-I) had learning difficulties. Corneal opacity and lipoid degeneration were documented in only one patient (4-I) at the age of 25 years. We also noticed that four patients had a metallic voice.

\section{Molecular studies}

Genomic DNA was extracted from peripheral blood leukocytes of the affected individuals and parents by standard methods obtained after informed consent. PCR amplification of the 11 exons of the gene was performed in a total volume of $50 \mu \mathrm{l}$, containing $100 \mathrm{ng}$ of template DNA, $1 \times$ PCR reaction buffer (Roche), $200 \mu \mathrm{M}$ of each nucleotide, $75 \mathrm{ng}$ of each primer (table 2), and $1.5 \mathrm{U}$ of Taq DNA polymerase (Roche). DMSO $1 \%$ was added to all the reactions except for exons 1 , 2 , and 3 where DMSO $10 \%$ was used. Experimental conditions were: denaturation at $96^{\circ} \mathrm{C}$ for 2 min, then 35 cycles of denaturation at $95^{\circ} \mathrm{C}$ for $15 \mathrm{~s}$, annealing at $60^{\circ} \mathrm{C}$ for $30 \mathrm{~s}$, extension at $72^{\circ} \mathrm{C}$ for $30 \mathrm{~min}$. In the final cycle, the extension lasted $10 \mathrm{~min}$. PCR products $(5 \mu \mathrm{l})$ were analysed by electrophoresis and visualised by ethidium bromide staining.

Direct sequencing of amplification products was performed on an ABI PRISM 310 sequencer. The results were compared to control sequences and to the sequence of clone LAl6316G12. For web-based database homology searches, we used BLAST and FASTA software.

\section{RESULTS}

\section{Clinical manifestations}

The clinical findings and mutations of the patients studied here are presented in table 1. Increased serum lysosomal enzyme activity level and/or low activity level in cultured fibroblasts were present in $14 / 14$ patients. Phosphotransferase activity towards artificial acceptor for phosphate ( $\alpha$-methylmannoside) was normal which was consistent with the diagnosis of ML III complementation group C in most of the patients. Unfortunately, we could not study the other Druze and Turkish patients.

Genomic organisation of the gamma subunit unit UDP$\mathrm{N}$-acetylglucosamine-1-phosphotransferase (GNPTAG) gene

The sequence of the gamma subunit of the UDP- $N$ acetylglucosamine-1-phosphotransferase gamma subunit gene (GNPTAG) has been reported in a previous study. ${ }^{10} \mathrm{~A}$ computerised BLAST study using the $5^{\prime}$ end of this CDNA sequence allowed us to identify a $100 \%$ similarity with the CAB56184 mRNA at locus AF302786 (EMBL: AL031709, AF302786, AE006467). Alignment of this mRNA with the genomic sequence of clone LAl6-316G12 showed that the gene consists of 11 exons spanning $11.13 \mathrm{~kb}$ of genomic DNA. Interestingly, the average intron size is $200 \mathrm{bp}$, while the size of the third intron is $9 \mathrm{~kb}$. This structure was consistent with the exon prediction of fgenes and Genscan. Each splice donor and acceptor site of the gene contained the canonical consensus sequences (table 2). Recently, the GNPTAG has been assigned to clone MGC 26283 and IMAGE 4824054 and reported as CAB56184, c316G12.3, or GNPTAG. ${ }^{11}$

\section{Mutations analysis}

Mutations on both alleles were detected by direct sequencing of the 11 exons of the GNPTAG gene in 14/14 patients. All the mutations segregated with the disease. They were located between exons 4 and 8 of the gene. The mutant genotypes are summarised in table 1. They include six novel mutations, namely, three frameshift mutations (c.608insC, c.445delG, c.379del13 bp), one nonsense mutation (R66X), one missense mutation (G106S) and one splice mutation (IVS5-1G>C). The patients were homozygotes for the mutant genotype in 7/8 families. Patient 8-I was a compound heterozygote for a paternally inherited splice mutation (IVS5-1G>C) and a maternally inherited nonsense mutation (R66X). RT-PCR experiments showed that the mutation (IVS5-1G $>$ C) caused the skipping of exon 6 (fig l). Patient l-I was homozygous for the G106S missense mutation. His parents were heterozygotes and study of 100 chromosomes derived from healthy unrelated individuals from the same ethnic background failed to identify this G106S amino acid change. Interestingly, the previously reported c.500insC mutation, ${ }^{10}$ is described here in three families of Jewish-Tunisian origin.

\section{DISCUSSION}

Here we report on GNPTAG mutations in 14 patients belonging to eight unrelated ML III families. We have previously reported on the c.500insC mutation in three families of Druze and Muslim origin. The cytosine insertion, reported here in Jewish-Tunisian patients belonging to three families occurred in a repeated sequence of cytosine and in a $\mathrm{CpG}$ island, which might have triggered the recurrence of this mutation. The c.608insC mutation (exon 8) also occurred in the context of a six-cytosine repeat; this could be due to slippage during DNA replication resulting in gains or losses of repeats. The two frameshift mutations, that is the c.445delG (exon 7) and c.379dell3 bp (exon 6), led to a premature stop codon at the same 161 codon. The splice mutation (IVS5$\mathrm{IG}>\mathrm{C}$ ) caused the skipping of exon 6 (fig 1 ). This mutation as well as the nonsense mutation (R66X) is predicted to severely damage the protein product. 
Here, we also emphasise joint and cardiac involvement in ML III. Stiffness of the small finger joints and/or claw hand (fig 2) was present in 11/14 patients. Hand involvement was already present in young patients (5-I, 7-I) at the age of 5 and 6 years and should be regarded therefore as suggestive of ML III. Freisinger et al ${ }^{12}$ reported on two ML III sibs with isolated involvement of the hip joint and no symptoms of storage disease. Here patient 5-II also presented with isolated hip involvement. On the other hand, three patients reported here had a thickened aortic valve and aortic regurgitation. The cardiac involvement in patients with ML III has already been reported by Kelly et al ${ }^{2}$ and Satoh et al. ${ }^{13}$ This suggests that ML III patients should undergo a careful cardiac evaluation and follow-up in order to prevent severe valvular complications.

Although most patients attended a regular school with adequate achievement, 1/14 had some learning disabilities. Age-dependent severity was noted in the oldest patients (2-I, 2-II) who were more severely affected. Sex-dependent severity, already reported by Brik et $a l^{14}$ and Melhem et $a l^{15}$ was illustrated by the less affected female patient (4-II) compared to her brother (4-I).

The family of Turkish origin illustrates the intra-familial variability of the disease. ${ }^{16} 17$ Indeed, the clinical phenotypes varied from a classical form (5-I) to an isolated hip involvement form in his first-cousin (5-II) of the same age and sex, and even no symptoms in his sister and brother (5-III, 5-IV).

In conclusion, we have shown that the GNPTAG gene is mutated in all patients belonging to the eight families studied. This result strongly suggests that despite the existence of at least three complementation groups, the UDP- $N$-acetylglucosamine-1-phosphotransferase gamma subunit plays a major role in mucolipidosis type III. Systematic complementation studies of a larger number of ML III patients and clarification of the molecular basis of ML III type A will enable evaluation of the relative frequencies of the ML III types. Severity of the disease cannot yet be predicted on the basis of type of mutation. Functional analyses might give some additional insights into the mechanisms underlying the trafficking of lysosomal enzymes to the lysosome. We hope that these results will help in providing accurate carrier detection in families at risk.

\section{ACKNOWLEDGEMENTS}

We thank Dr Yaacov Frishberg, for his help in the preparation of the manuscript.

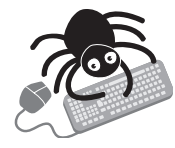

Data access: HGMD, Human Gene Mutation Database (http://archive.uwcm.ac.uk); BLAST (http://www.ncbi.nlm.nih.gov/BLAST/); FASTA (http://www2.ebi.ac.uk/fasta3/); OMIM (http:// www.ncbi.nlm.nih.gov/omim/).

\footnotetext{
Authors' affiliations

A Raas-Rothschild, R Bargal, O Goldman, E Stemmer, Z Ben-Neriah, G Bach, M Zeigler, Department of Human Genetics, Hadassah University Medical Center, Jerusalem, Israel

E Ben-Asher, T Olender, Department of Molecular Genetics, Weizmann Institute of Science, Rehovot, Israel

J E M Groener, Departments of Pediatrics and Clinical Genetics, Leiden University Medical Center, Leiden, The Netherlands

A Toutain, Service de Génétique CHU de Tours Hôpital Bretonneau, Tours, France

H Flusser, Child Development Unit, Soroka University Hospital, Beer Sheva, Israel

F A Beemer, Department of Medical Genetics, University Medical Center, Utrecht, The Netherlands

M Penttinen, Clinical Genetics Unit, Turku University Central Hospital, Turku, Finland
}

A J J T Rein, Division of Pediatric Cardiology, Hadassah University Medical Center, Jerusalem, Israel

This study was supported by a grant from the Vaincre les Maladies Lysosomales Association (VML), France, and by a grant from the Keren Meshoutefet of the Hebrew School of Medicine, Jerusalem (ARR). Additional support was from the Crown Human Genome Center at the Weizmann Institute of Science (WIS) and an Israeli Ministry of Science Culture and Sports grant to the National Laboratory for Genome Infrastructure at the WIS (EBA)

Conflict of interest: none declared.

Correspondence to: A Raas-Rothschild, MD, Department of Human Genetics, Hadassah University Hospital, Jerusalem, 91120, Israel; annick@md.huji.ac.il

Received 13 November 2003

Accepted 17 November 2003

\section{REFERENCES}

1 Maroteaux P, Lamy M. Hurler's pseudo-polydystrophy. Presse Med 1966;74(55):2889-92.

2 Kelly TE, Thomas GH, Taylor HA Jr, McKusick VA, Sly WS, Glaser JH, Robinow M, Luzzatti L, Espiritu C, Feingold M, Bull MJ, Ashenhurst EM, lves EJ. Mucolipidosis III (pseudo-Hurler polydystrophy): clinical and laboratory studies in a series of 12 patients. Johns Hopkins Med J 1975; 137(4):156-75.

3 Kornfeld S, Sly WS. I-cell disease and pseudo-Hurler polydystrophy: disorders of lysosomal enzyme phosphorylation and localisation. In: Scriver CR, Beaudet AL, Sly WS, Valle D, eds. The metabolic basis of inherited disease, 8th ed, vol III. New York: McGraw-Hill, 2001:3469-82.

4 Kornfeld S. Trafficking of lysosomal enzymes in normal and diseases states. J Clin Invest 1986:77:1-6.

5 Sly WS. The missing link in lysosomal enzyme targeting. J Clin Invest 2000;105(5):563-4.

6 Varki AP, Reitman ML, Kornfeld S. Identification of a variant of mucolipidosis III (pseudo-Hurler polydystrophy): a catalytically active $\mathrm{N}$ acetylglucosaminyl phosphotransferase that fails to phosphorylate lysosomal enzymes. Proc Natl Acad Sci USA 1981;78(12):7773-7.

7 Honey NK, Mueller OT, Little LE, Miller AL, Shows TB. Mucolipidosis III is genetically heterogeneous. Proc Natl Acad Sci USA 1982;79:7420-4.

8 Little LE, Mueller OT, Honey NK, Shows TB, Miller AL. Heterogeneity of Nacetylglucosamine 1-phosphotransferase within mucolipidosis III. J Biol Chem 1986;261(2):733-8.

9 Bao M, Booth JL, Elmendorf BJ, Canfield WM. Bovine UDP-Nacetylglucosamine: lysosomal-enzyme $\mathrm{N}$-acetylglucosamine-1 phosphotransferase. I. Purification and subunit structure. J Biol Chem 1996;271(49):31437-45.

10 Raas-Rothschild A, Cormier-Daire V, Bao M, Genin E, Salomon R, Brewer K, Zeigler M, Mandel H, Toth S, Roe B, Munnich A, Canfield WM. Molecular basis of variant pseudo-Hurler polydystrophy (mucolipidosis IIIC). J Clin Invest 2000; 105(5):673-81

11 Strausberg RL, Feingold EA, Grouse LH, Derge JG, Klausner RD, Collins FS, Wagner L, Shenmen CM, Schuler GD, Altschul SF, Zeeberg B, Buetow KH, Schaefer CF, Bhat NK, Hopkins RF, Jordan H, Moore T, Max SI, Wang J, Hsieh F, Diatchenko L, Marusina K, Farmer AA, Rubin GM, Hong L, Stapleton M, Soares MB, Bonaldo MF, Casavant TL, Scheetz TE, Brownstein MJ, Usdin TB, Toshiyuki S, Carninci P, Prange C, Raha SS, Loquellano NA, Peters GJ, Abramson RD, Mullahy SJ, Bosak SA, McEwan PJ, McKernan KJ, Malek JA, Gunaratne PH, Rickards S, Worley KC, Hale S, Garcia AM, Gay L, Hulyk SW, Villalon DK, Muzny DM, Sodergren EJ, Lu X, Gibbs RA, Fahey J, Helton E, Ketteman M, Madan A, Rodrigues S, Sanchez A Whiting M, Madan A, Young AC, Shevchenko Y, Bouffard GG, Blakesley RW, Touchman JW, Green ED, Dickson MC, Rodriguez AC, Grimwood J, Schumtz J, Myers RM, Butterfield YS, Krzywinski MI, Skalska U, Smailus DE, Schnerch A, Schein JE, Jones SJ, Marra MA; Mammalian Gene Collection Program Team. Generation and initial analysis of more than 15,000 fulllength human and mouse cDNA sequences. Proc Natl Acad Sci USA 2002;99(26): 16899-903

12 Freisinger P, Padovani JC, Maroteaux P. An atypical form of mucolipidosis III. J Med Genet 1992;29(11):834-6.

13 Satoh Y, Sakamoto K, Fujibayashi Y, Uchiyama T, Kajiwara N, Hatano M. Cardiac involvement in mucolipidosis. Importance of non-invasive studies for detection of cardiac abnormalities. Jpn Heart J 1983;24(1):149-59.

14 Brik R, Mandel H, Aizin A, Goldscher D, Ziegler M, Bialik V, Berant M. Mucolipidosis III presenting as a rheumatological disorder. J Rheumatol 1993;20(1):133-6

15 Melhem R, Dorst JP, Scott Cl Jr, McKusick VA. Roentgen findings in mucolipidosis III (pseudo-Hurler polydystrophy). Radiology 1973;106(1):153-60.

16 Ward C, Singh R, Slade C, Fensom AH, Fahmy A, Semrin A, Sjovall A, Talat A, Hasilik A, Klein I, Benson PF. A mild form of mucolipidosis type III in four Baluch siblings. Clin Genet 1993;44(6):313-9.

17 Tylki-Szymanska A, Czartoryska B, Groener JE, Lugowska A. Clinical variability in mucolipidosis III (pseudo-Hurler polydystrophy). Am J Med Genet 2002;108(3):214-8. 